\title{
米国における歴史保全地役権プログラムに関する研究 A STUDY ON THE HISTORIC CONSERVATION EASEMENT PROGRAM IN U.S.
}

\author{
遠藤 新*
}

Arata ENDO

\begin{abstract}
Historic Conservation Easement Program (HCEP) is used for preserving historic buildings in U.S. from 1970s. If the conservation easements on historic buildings are donated in perpetuity to a charitable organization who aims a historic conservation, land owners of those buildings can get a charitable contribution as a federal income tax deduction. In order to introduce HCEP like conservation program into Japan, there are three subjects such as to establish an "conservation easement", to establish a tax deduction system, and to design a flexible system which can custom-made by local conservation organizations.
\end{abstract}

Keywords : Conservation Easement, Tax Deduction, Charitable Contribution, Easement Value 保全地役権，所得控除，慈善寄付金，地役権価格

\section{1. 研究の枠組み}

\section{1 背景と目的}

歴史的環境の保全を目的とする多様な手法の充実や意識の醸成は、 成熟社会を迎えた我が国が取り組むべき今日的課題である。歴史的 環境保全に関して蓄積の多い米国には、歴史保全地役権プログラム (Historic Conservation Easement Program ${ }^{1)}$ 、以下 HCEP) という 我が国にないプログラムがあり効果を上げている。HCEP とは、土地 所有者が当該土地の環境を保全するために、その土地の所有権の一 部である地役権を、民間非営利の環境保全団体もしくは政府機関等 に譲渡することを可能にする制度と、一定条件を満たした保全地役 権の譲渡に対しては連邦所得税の減税措置を認めるという二つの制 度を組み合わせることで歴史的環境の保全を促すプログラムである。 HCEP に関連する日本語の既往研究には、新澤 (2002) 坂井 (2002) 等による保全地役権概念の整理、西村（2004、1997）による制度紹 介や矢作（1989）の事例報告がある。また、英語文献では Stephen L. Kass他（1993）の著書がプログラムを詳しく紹介している。しか し、これらの研究においては、保全地役権譲渡に際しての運用課題 や減税措置の具体的適用方法といった点の解明までは至っておらず、 従ってプログラム全体としての特徵や運用にまつわる課題の解明作 業も残されたままである。

そこで本研究では、保全地役権概念の分析、HCEP における保全地 役権の譲渡・維持管理に関する課題分析、減税措置の適用に関する 課題分析を行い、歴史的環境の保全手法としての HCEP の利点と同手 法を日本に導入する場合の課題の考察を行うことを目的としたい。

本研究では保全地役権の中でも歴史的環境に関するものに対象を 絞る。本研究ではこれを歴史保全地役権と呼ぶことにする。なお、 保全地役権の概念を自然環境の保全に適用したプログラムも米国で は活用されており、環境保全に対する近年の問題意識の高まり等を 背景に、研究も進められている ${ }^{2)}$ 。しかし、歴史的環境に対する保全
地役権と自然環境に対する保全地役権では、プログラムの考え方は 共通していても、制度の詳細や運用方法が全く異なるため、本研究 の対象からは除外する。

\section{2 研究の方法}

第一に、既往研究の整理および統一保全地役権法の分析から、保 全地役権概念の要点およびプログラム運用の一般的手続きを明らか にする。ここでは、保全地役権全般を扱うが、歴史保全地役権とそ れ以外の違いに留意して議論を進める。第二に、文献資料の情報を 元に本プログラムを運用する組織の動向を整理した上で幾つかの組 織を選定し、同組織の現地調査により収集した一次資料の分析から、 歴史保全地役権の設定方法、歴史保全地役権の取り扱いルール、歴 史保全地役権設定後の維持・管理方法等を明らかにする。地役権が 適切に保全されていることを確認するため、保全地役権の譲渡を受 けた組織には、地役権を設定した建物の調查および現状変更を審査・ 許可する権限が契約によって与えられる。契約に定められた取り扱 い手続きや現状変更の許容範囲、毎年の点検作業の具体的内容等を 分析することにより、保全団体の役割を明らかにする。第三に、文 献資料の情報を元に減税措置の仕組みを整理した上で、現地調查に より収集した一次資料の分析から、減税措置の具体的な適用方法お よび運用時の課題等を明らかにする。最後に、以上の分析結果を踏 まえて、HCEP を日本に適用する際の課題について考察する。なお、 事例分析の対象は次の方法で抽出している。まず、内国歳入庁が庁 内情報および各州歴史保全室の情報を通じてリス卜化した保全地役 権を保有する主な組織（全 105 組織、2003 年時点） ${ }^{3)}$ の中から、歴 史的建造物（建物・外観・内観）の保全地役権を所有する 35 組織を 抽出した（表 3)。次に、社会的認知及び技術蓄積の多さを念頭に長 期間活動を持続してきた組織に着目して、米国を代表する歴史保全 団体の The National Trust for Historic Preservation（1973 年設 立）よりも活動期間が長い 9 組織を仮に選び、HCEP 担当者と日程調 
整が実現した 5 組織 ${ }^{4)}$ に対して現地調查を実施した。その結果、現 地調查において個々の保全地役権の契約書や地役権の価格算定書な ど個別情報の開示と裏付け資料の提供に応じてくれた 2 組織（San Antonio Conservation Society, Cincinnati Preservation Association) が保有する保全地役権を本研究では分析対象として選定した。なお、 調査は 2004 年〜 2008 年の期間に 5 回に分けて実施した。

\section{2. 保全地役権とは何か?}

\section{1 米国における地役権}

米国のコモンローにおける地役権には付随地役権 (easement appurtenant） と対人地役権（easement in gross）の二つの種類が ある ${ }^{5)}$ 。付随地役権とは、他人の土地 $\left(=\right.$ 要役地 $\left.{ }^{6)}\right)$ を自分の土地 $(=$ 承役地）の便益のために利用寸る権利であり、二つの土地の所有者 間で契約により発生する権利である ${ }^{7)}$ 。一方の対人地役権とは、土 地の便益のためではなく、人の便益のために他人の土地を利用する 権利である。従って、要役地が存在せず、隣接の土地所有者でない 人でも保有することが可能である。本研究の対象とする保全地役権 はこの対人地役権に分類される。なお、現在の日本では対人地役権 は認められていない8)。

\section{2 保全地役権の特徵}

ある土地や建物等の保全を目的として当該不動産に設定する地役 権を保全地役権と呼ぶ。統一保全地役権法においては「自然環境や 歴史的環境の保全を目的とする制限・義務の課せられた不動産の所 有者が有する非所有的権利（non-possessory interest）」と定義され ている ${ }^{8)}$ 。米国における土地の所有権は様々な権利の束として認識 されている。その土地に関する様々な権利の中から保全目的に反し た活動を行う権利だけを切り離し、それを制限したものだと言える。 なお、保全地役権は土地収用の権限を制限しない。

保全地役権の保有が可能な主体は、不動産の権利を持つことがで きる政府機関、もしくは自然環境ならびに歴史的環境の保全を目 的とする慈善法人 ・ 慈善協会 - 慈善信託 (charitable corporation、 charitable association、charitable trust）の何れかに法律で限定さ れている。土地所有者からこれらの団体一の譲渡契約が成立して初 めて保全地役権に関する様々な権利・義務が発生する。保全地役権 の設定された土地を他者に譲渡することは可能だが、保全地役権に 関する情報は土地台帳に記録され、土地所有の承継人を拘束する。

保全地役権には歴史的環境に対して設定される地役権と自然環境 に対して設定される地役権がある（表 1 ）。本研究の対象とする歴史 的環境の保全地役権は、建物内外の一部から全体まで様々な部位に 任意に設定可能である。土地所有者や保全団体の意向に沿ってオー ダーメイド可能である。建物の部位に保全地役権が設定されても、 建物所有者は当該建物をそのまま私的に利用し続けることができる。

表 1 保全地役権の主な設定対象（筆者作成）

\begin{tabular}{|c|c|c|}
\hline 種類 & 目的 & 項目 \\
\hline $\begin{array}{l}\text { 歴史的環境の } \\
\text { 保全地役権 }\end{array}$ & $\begin{array}{l}\text { 建築や構造物等におけ抒け歴史的・ } \\
\text { 文化的・考古学的側面の保護 }\end{array}$ & 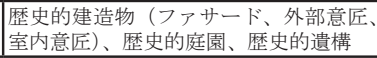 \\
\hline $\begin{array}{l}\text { 自 然 環 境 } \\
\text { 保全地役権 }\end{array}$ & $\begin{array}{l}\text { 空地における自然環境や眺望の保 } \\
\text { 謢 }\end{array}$ & 農地、湿地、水面、山林 \\
\hline
\end{tabular}

対象となる不動産および譲渡先の組織が一定条件を満たす場合、 保全地役権を譲渡した土地所有者は連邦所得税の減税措置を受ける
ことができる（第 4 章で詳述）。この場合、保全地役権の設定時に一 定の手続きが求められ、保全地役権設定後はそれを維持するための 義務行為が発生する。手続きとしては（1）設定箇所の選択（2）設 定箇所における初期状態の記録（3）保全地役権の鑑定評価（4）不 動産所有者と譲渡を受ける団体との契約、という4 つの段階が求め られる。義務行為として、保全地役権を譲渡された団体は地役権設 定箇所が適切に保全されているかどうかの点検調查を定期的に行う 必要がある。その結果を文書と写真等によって記録し、土地所有者 が変わっても保全地役権が適切に承継されるように記録文書を保存 しておくことが義務づけられている。

\section{3 保全地役権法の制定}

地役権を用いた最初の環境保全事例は 1880 年代後半のボストン市 における公園の保護だとされる。その後は、1930 年代に国立公園管 理局が自然環境の保護を目的としてブルーリッジ山脈およびナチェ ズ・トレース・パークウェイ沿いの土地の地役権を取得、1950 年代 前半にはウィスコンシン州が眺望景観の保護を目的としてミシシッ ピ川沿い道路周辺の地役権を取得するなど、自然環境を保全する手 法としての地役権を取得する試みが重礼られた。こうした動きを背 景として 1969 年にマサチューセッツ州とメーン州で保全地役権法が 成立した。

歴史的環境については、アナポリス歴史協会が 1960 年代にメリー ランド州アナポリス市の中心部にある聖アン教会の付属施設棟を保 存するために外壁の地役権を取得したのが最初とされる。同協会は 基金による歴史的建造物の買取・修復・転売を行っていたが、価格 高騰によって歴史的建物の買取が困難になったことが背景にある。 その後，1970 年代から各州で保全地役権に関する法律が定められ、 1981 年 8 月には統一州法委員会全国会議 ${ }^{9)}$ によって統一保全地役権 法（Uniform Conservation Easement Act）が作成された。現在で は全米 48 州並びにワシントン特別区の全てが保全地役権に関する法 を制定している。23 州およびワシントン特別区で統一保全地役権法 が採用され、残り 25 州は独自の保全地役権法を制定している。この ように、米国で保全地役権が普及した背景には、各州の立法の努力 があったと言える。

\section{4 保全地役権と移転可能な開発権の相違}

HCEP を用いた歴史的建造物の保護は、しばしば開発権の移転 (Transference of Development Rights $\left.{ }^{10}\right)$ による歴史的建造物の保 護と比較される ${ }^{11}$ 。 。両者を比較することで保全地役権の輪郭がより 明確になることから、本節では両者の相違点を分析する（表 2)。

両者は歴史的建造物を保護することによって、その土地の潜在的 な開発可能性が損なわれることに対し、何らかの見返り措置を認め ているところに共通点がある。しかし、幾つかの点で根本的な違い がある。まずTDR の場合は、損なわれる開発権の一部を他の土地一 移転することにより開発機会を確保するか、開発権の一部を売却す ることによって金銭的対価を得ることができる。一方、HCEP の場合 は保全地役権を設定することで開発権が損なわれるが、建物保護に 起因する不動産価值の損失分は、税制優遇措置によって金銭的対価 を得ることができる。

また、TDR の場合は歴史的建造物の保護が別の開発の促進につな がる側面も持っているが、HCEP の場合は開発権の一部が他敷地に移 動しないため、他の開発の促進にはつながらない。 
表 2 歴史的建造物保護手法としての HCEP と TDR の違い（筆者作成） 保護に対する代替措置

HCEPによる建物変更の制限に対する 所得控除が動機付けとして働く前提として、控除 歴史的建造物 見返り措置として、所得額以上の所得が必要である。 の保護控除が得られる。

開発権の移転土地利用の制限に対する 別の土地に開発権が上乗サされ、開発事業が促進 による歷史的見返り措置として、他のされる。しかし、移転できる地域が限られており、、 建造物の保護 土地一の開発権の移転・しかも行政上の許可等を要するなどの制約も多 売却ができる。

\section{3. 歴史保全地役権の適用実態}

\section{1 歴史保全地役権を保有する組織の動向}

1.2 節（研究の方法）に示す方法で抽出した 35 組織（表 3）を対 象として、歴史保全地役権を保有する組織の動向を探る。

まず、行政組織は 3 団体（表内番号 6，31，36）のみで、大半の 32 組織は非行政の慈善団体となっている。しかし、その組織の活動 範囲として特定の地区に限定する組織は 3 団体（番号 $2 ， 30 ， 32 ）$ のみで、残り 32 組織は市域以上の広範囲から保全地役権を取得して いる。また、35 組織中 21 組織が歴史的建造物に関する保全地役権 以外の保全地役権も保有している。これらのことから、保全地役権 の保有は必ずしも地域に密着した歴史保全活動と密接な関係にない ことがわかる。保全地役権の維持管理に地域性は必ずしも問われて いないようである。

\section{2 San Antonio Conservation Society(SACS) の場合}

SACS は 1924 年に設立された 80 年以上の活動実績を有する保全団 体である。調查を行った 2008 年 3 月の時点で 22 件の保全地役権を 保有する。ここから自然環境 1 件、庭園 3 件、資料不備 3 件を除く 15 件が建物の保全地役権となっている。

\section{(1) 歴史保全地役権の設定箇所}

15 件の建物における保全地役権の設定箇所は多様である（表 4)。 契約書の中では保全地役権を設定している䇢所を具体的に表記し、 その歴史的・建築的特徴は設定時の状況を撮影した写真を添付する ことで記録している。屋外の地役権は大半がファサードを設定対象 としている。ファサードは面する通りの名称と壁面の高さ・幅の数 值によって位置を特定している。また、ファサード以外では当該建 物の歴史的特徵が表れている部位があれば、そこに保全地役権が設 定されている。例えばAztec 劇場（表 5) では劇場内部各所におい て保全地役権を詳細に設定している。どこまで詳細に設定するかは その歴史的建物の建築的特徵をどのように記述するかという問題で あり、ケースバイケースだと考えられる。

表 4 SACS の保有する歴史保全地役権の設定箇所（筆者作成）

\begin{tabular}{|c|c|}
\hline \multirow{2}{*}{ 場所 } & 設定対象（括弧内の数字は件数） \\
\hline & 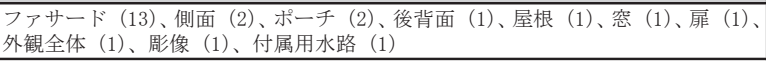 \\
\hline
\end{tabular}

表 5 Aztec 劇場における保全地役権の設定箇所（筆者作成） 種類

\begin{tabular}{|c|c|}
\hline $\begin{array}{l}\text { ファザ } \\
\text { ード }\end{array}$ & 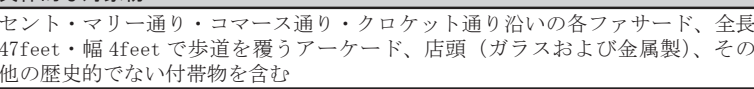 \\
\hline ロビー & 正面玄関ロビー、チケット売り場+ホワイエ、コマース通りに面する玄関ホール \\
\hline 観客席 & 歴史的な内装の客席、バルコニー、舞台開口部（プロセニアム）、天井板 \\
\hline 家具等 & 劇場に設置された歴史的価值のある彫刻および椅子 \\
\hline その他 & 上記以外の建筮的に重要な内装部分（ナショナルレジスター歴史的建造物の登録 \\
\hline
\end{tabular}

表 3 保全地役権を保有する組織（105 件から以下 $\mathrm{a} ・ \mathrm{~b} ・ \mathrm{c} 3$ 種類の全ての保全地役権を持つ組織を抽出）(参考文献 15 をもとに筆者作成） ※保全地役権の種類：a. 建物、b. ファサード、c. 内部、d. 庭園、e. 史跡、f. ランドスケープ・眺望、g. 農地・その他の自然環境

\begin{tabular}{|c|c|c|c|c|c|c|c|c|c|c|c|}
\hline & 組織名称 & 設立年 & 州 & 活動範囲 & $\mathrm{a}$ & $\mathrm{b}$ & $\mathrm{c}$ & d & $\mathrm{e}$ & & \\
\hline & San Antonio Conservation Society & 1924 & $\mathrm{TX}$ & Bexar 郡抽よ゙周辺郡 & $\mathrm{O}$ & 0 & 0 & & & & \\
\hline & Historic Annapolis Foundation & 1952 & $\mathrm{MD}$ & アナポリス歴史地区 & 0 & 0 & 0 & & & & \\
\hline & \begin{tabular}{|l|} 
Cambridge Historical Commission \\
\end{tabular} & 1963 & $\mathrm{MA}$ & ケンブリッジ市 & 0 & $\mathrm{O}$ & 0 & & & & \\
\hline & \begin{tabular}{|l} 
Cincinnati Preservation Association \\
\end{tabular} & 1966 & $\mathrm{OH}$ & オ八イオ州南西部・ケンタッキー州北部 & 0 & 0 & 0 & & & 0 & \\
\hline & Athens-Clarke Heritage Foundation, Inc. & 1967 & GA & Athens-Clarke 郡および周辺郡 & 0 & 0 & 0 & & & & \\
\hline 6 & Virginia Department of Historic Resources & 1968 & $\mathrm{VA}$ & バージニア州 & $\mathrm{O}$ & 0 & 0 & & & & \\
\hline & Maryland Historical Trust & 1969 & $\mathrm{MD}$ & メリーランド州 & 0 & O & 0 & & O & & \\
\hline & Historic Landmarks Foundation of Indiana & 1970 & IN & インディアナ州 & 0 & 0 & 0 & & & & \\
\hline 9 & Rhode Island Historical Preservation \& Heritage Commission & 1970 & $\mathrm{RI}$ & ロードアイランド州 & $\mathrm{O}$ & 0 & $\mathrm{O}$ & 0 & $\mathrm{O}$ & O & \\
\hline 10 & The National Trust for Historic Preservation & 1973 & $\mathrm{DC}$ & 全米 & $\mathrm{O}$ & $\mathrm{O}$ & $\mathrm{O}$ & 0 & $\mathrm{O}$ & $\mathrm{O}$ & $\bar{O}$ \\
\hline 11 & Preservation Society of Chapel Hill & 1973 & $\mathrm{NC}$ & Chapel Hill 市+ Orange 郡 & $\mathrm{O}$ & 0 & $\mathrm{O}$ & 0 & & & \\
\hline 12 & The Alabama Historical Commission & 1974 & $\mathrm{AL}$ & アラバマ州 & $\mathrm{O}$ & o & $\mathrm{O}$ & o & $\mathrm{O}$ & & \\
\hline 13 & Preservation League of New York State & 1975 & NY & 二ューヨーク州 & $\mathrm{O}$ & $\overline{0}$ & $\mathrm{O}$ & & & & \\
\hline 14 & Landmarks Preservation Council of Illinois & 1976 & $\mathrm{IL}$ & \begin{tabular}{|l|l} 
イリノ州 \\
\end{tabular} & 0 & 0 & $\mathrm{O}$ & 0 & & 0 & 0 \\
\hline 15 & Preservation Society of Asheville \& Buncombe County, Inc. & 1976 & $\mathrm{NC}$ & Asheville \& Buncombe 郡 & $\mathrm{O}$ & 0 & 0 & & & & \\
\hline 16 & New Jersey Historic Trust & 1978 & NJ & =ュージャージー州 & O & O & $\mathrm{O}$ & 0 & & O & \\
\hline 17 & The Preservation Society of Charleston & 1978 & $\mathrm{SC}$ & チャールストン市 & 0 & $\mathrm{O}$ & O & & & & \\
\hline 18 & Preservation Alliance for Greater Philadelphia & 1979 & $\mathrm{PA}$ & フィラデルフィアを中心とする大西洋側中央部一帯 & $\mathrm{O}$ & $\mathrm{O}$ & $\mathrm{O}$ & 0 & & 0 & \\
\hline 19 & Historic Charleston Foundation & 1979 & $\mathrm{SC}$ & チャールストン市,Beaufort,Berkeley,Charleston,Dorchester,Georgetown 郡 & $\mathrm{O}$ & O & $\mathrm{O}$ & $\mathrm{O}$ & $\mathrm{O}$ & $\mathrm{O}$ & \\
\hline 20 & \begin{tabular}{|l|} 
Dade Heritage Trust \\
\end{tabular} & 1982 & FL & \begin{tabular}{|l|l|} 
南フロリダ地域 \\
\end{tabular} & 0 & $\mathrm{O}$ & $\mathrm{O}$ & & & & \\
\hline 21 & Capital Area Preservation, Inc. & 1982 & $\mathrm{NC}$ & Wake 郡 & 0 & 0 & 0 & & & & \\
\hline 22 & Historic Preservation League of Oregon & 1983 & OR & Pacific Northwest & 0 & $\mathrm{O}$ & 0 & 0 & 0 & $\mathrm{O}$ & \\
\hline 23 & Nation Ford Land Trust & 1989 & $\mathrm{SC}$ & York 郡 & 0 & $\mathrm{O}$ & $\mathrm{O}$ & & $\overline{0}$ & & \\
\hline 24 & Landmarks Historic Trust & 1990 & MO & カンザスシティ都市圈 & $\mathrm{O}$ & 0 & $\mathrm{O}$ & 0 & & & \\
\hline 25 & Yampa Valley Land Trust & 1992 & $\mathrm{CO}$ & NW Colorado, Routt, Moffat, Jackson および Rio Blanco 郡 & 0 & 0 & 0 & & & & $\mathrm{O}$ \\
\hline 26 & Frank Lloyd Wright Building Conservancy & 1994 & $\mathrm{IL}$ & 全米 & 0 & $\mathrm{O}$ & $\mathrm{O}$ & & & & \\
\hline 27 & Manchester Historic Association & 1994 & $\mathrm{NH}$ & マンチェスター市 & 0 & $\mathrm{O}$ & 0 & & & & \\
\hline 28 & The Palmetto Trust for Historic Preservation & 1994 & $\mathrm{SC}$ & 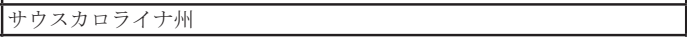 & 0 & $\mathrm{O}$ & 0 & 0 & & 0 & \\
\hline 29 & Maine Preservation & 1995 & $\mathrm{ME}$ & メーン州 & 0 & 0 & 0 & & & & \\
\hline 30 & \begin{tabular}{|l|} 
Adirondack Architectural Heritage \\
\end{tabular} & 1995 & NY & Adirondack Park 地区 & $\mathrm{O}$ & 0 & 0 & & & & o \\
\hline 31 & State of Delaware, Div. of Historical \& Cultural Affairs & 1997 & DE & デラウェア州 & 0 & 0 & $\mathrm{O}$ & 0 & 0 & $\mathrm{O}$ & \\
\hline 32 & Uptown Shelby Association, Inc. & 1998 & $\mathrm{NC}$ & アップタウン・シェルビー・ミュニシパル・サービス地区 & 0 & 0 & $\mathrm{O}$ & 0 & & 0 & \\
\hline 33 & First State Preservation Revolving Fund, Inc. & 2002 & $\mathrm{DE}$ & デラウェア州 & $\mathrm{O}$ & 0 & $\mathrm{O}$ & 0 & & 0 & \\
\hline 34 & New Hampshire Preservation Alliance & 2002 & $\mathrm{NH}$ & ニューハンプシャー州 & 0 & 0 & 0 & 0 & & $\mathrm{O}$ & \\
\hline 35 & Heritage Ohio, Inc. & 2002 & $\mathrm{OH}$ & \begin{tabular}{|l|l} 
オ八イオ州 \\
\end{tabular} & $\mathrm{O}$ & 0 & 0 & & & & \\
\hline & Office of Historic Alexandria & 不明 & VA & アレクサンドリア市 & $\mathrm{O}$ & $\mathrm{O}$ & 0 & 0 & & 0 & \\
\hline
\end{tabular}



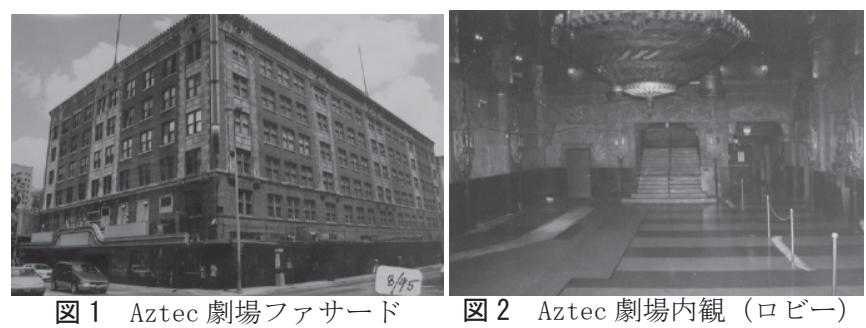

\section{（2）歴史保全地役権の取り扱い規則}

全ての契約書で修復 (rehabilitation)、維持管理 (maintenance)、 再建 (reconstruction) 、付加 (additions)、看板 (signs)、保険 (insurance) の 6 項目のあり方を定めており、その要点は以下の四 点にまとめられる。

第一に、修復、維持管理、付加、再建、看板の設置・撤去等とい った行為を建物所有者もしくはSACS のどちらが実施負担するかは契 約条項の中でケースバイケースに定められている。SACS は建物の保 全地役権を保有しているのであり、建物の所有権を保有しているわ けではない。従って、一般的には建物所有者がこうした行為の責任 を負うと考えられる。しかし、何らかの理由で建物所有者の負担を 軽減する必要がある場合などは、SACS 自身がこれら行為を負担する ものと考えられる。

第二に、修復、維持管理、付加、看板の設置といった行為を行う 場合は、連邦 - 州政府の定める所得控除を受けるための歴史的建造 物の修景基準と市のゾーニング条例に基づく看板設置基準を全て満 たし、かつ、市のゾーニング条例に基づく歴史地区の規制エリア内 に位置する場合はその修景基準を全て満たす必要がある。また、当 該行為の計画について SACS に対する事前相談が必要であり、SACS の承認を得なければ行為を実施することができない。また、連邦・ 州政府の修景基準との整合性を得るため、計画案は州歴史保全室の 承認も得なければならない。このように、現状変更に関する情報は 全て事前にSACS が把握できる仕組みとなっている。

第三に、再建のルールとして、自然災害・不慮の事故・等により 建物が破損した場合、それが建物全体の $50 \%$ 未満であれば保全当初 の状態に復旧させなければならないが、破損が $50 \%$ 以上の状態であ れば、建物所有者および連邦・州・市政府の承認を得る限りにおい て建物の取り壊しを行うことができる。

第四に、災害等による建物の全壊・半壊時に備えて、建物所有者 は建物の保険に加入しなければならない。

\section{(3) 保全状態の点検調査}

SACS は保全地役権の設定箇所の保存状態を毎年点検する。この調 查は過去の記録写真をもとに SACS の専門スタッフ 1 人が実施する。

現地点検の前には質問票を地権者に送付して、保全地役権設定箇 所における現状変更の有無や今後の現状変更に関わる計画や希望等 を申告してもらう。事前送付質問票には 4 つの項目がある（表 6)。 各項目の Yes/No をチェックした上で、Yesに該当する場合は詳細を 記述する形式になっている。問 1 は当該年における工事有無の確認 を求めているが、問 $2 \sim 4$ は今後の現状変更の可能性を尋ねている。 先述した通り、改修、修繥、付加、看板設置といった現状変更を伴 う工事を行う場合、その計画案は必ずSACS の事前承認を得る手続き が契約に定められている。従って、SACS は質問票調查や現地点検調
查を行う以前に、工事の有無やその内容に関する情報は持っている ことになる。従って、質問票調査で特に重要なのは問 $2 \sim 4$ であり、 現地点検調查は工事結果を確認する意味合いが強いと言える。

表 6 地権者に事前送付寸る質問票の項目（SACS 内部資料から筆者作成）

\begin{tabular}{|c|c|}
\hline & 質問 \\
\hline 問 1 & 前回の点検時以降、外観に影響を及ぼす物的な変更を行ったか？ \\
\hline 問 2 & 今年または近年中に外観に影響を及ぼす物的な変更を行うつもりはあるか？ \\
\hline 問 3 & 近い将来、建物の用途やプログラムを変更する計画はあるか? \\
\hline 問 4 & 近い将来、建物の所有に何らかの変更が生じると思うか？ \\
\hline
\end{tabular}

\section{3 Cincinnati Preservation Association(CPA) の場合}

$\mathrm{CPA}$ は 2005 年 3 月の調查時点で 72 件の歴史保全地役権を保有し ている。このうち、保全地役権の譲渡に関する契約書の全文が入手 できた 1 事例（Cincinnati Bell）を本節の分析対象とする ${ }^{13)}$ 。

\section{(1) 歴史保全地役権の設定箇所}

保全地役権の設定箇所は南・東・北の 3 面のファサードである。 西ファサードは 1974 年に増築的改修が行われたため保全地役権の設 定箇所から除外されている。保全地役権の設定されたファサードは、 その構成要素が詳細に分類され、保全地役権の内容が明快に記述さ れている（表 7)。但し、数值的な記述は建物の高さや幅など外形に 限定され、他項目は全て言葉による説明的な記述になっている。

表 7 ファサード保全地役権の構成要素（参考文献 23 から抜粋）

\begin{tabular}{|c|c|}
\hline 構成要素 & \begin{tabular}{|l} 
詳細項目 \\
\end{tabular} \\
\hline 基本構成 & 立面の数、建物階数、ペントハウス有無、各立面の空の数 \\
\hline 外壁 & 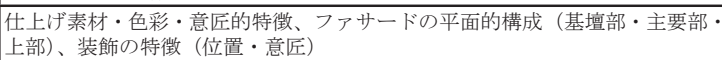 \\
\hline 1 階の空 & 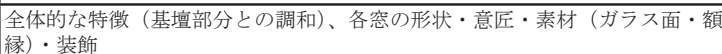 \\
\hline 正面玄関 & 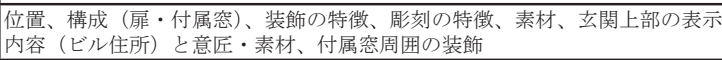 \\
\hline 玄関周り & 空の意匠・装飾、玄関灯の位置・素材・形態的特徴・色彩 \\
\hline 上部階の空 & 特徴の異なる空ごとに、位置・大きさの特徴・空枠の特徵（意匠・素材・装飾） \\
\hline 寸法 & 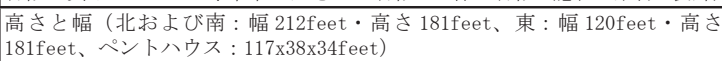 \\
\hline その他 & 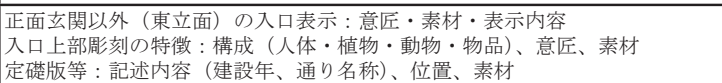 \\
\hline
\end{tabular}

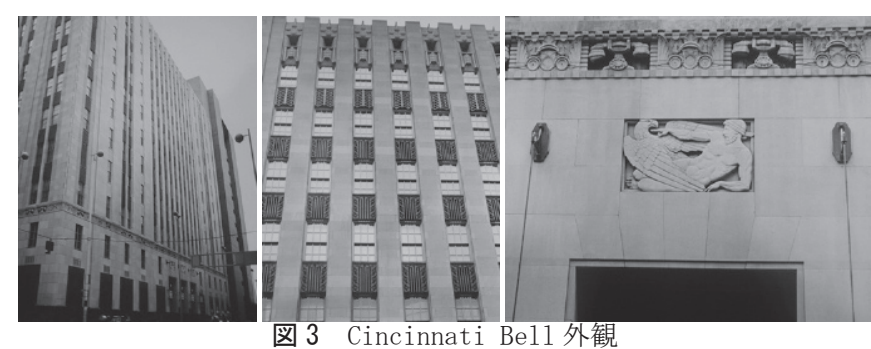

(左から北面ファサード、上部階空、玄関の彫刻)

\section{（2）歴史保全地役権の取り扱い規則}

建物の現状変更に関する規則の要点は、以下五点にまとめられる。 第一に、保全目的を持ち、かつ、保存・保護または建物の歴史的 建築としての特徵と矛盾しない方法であれば、地権者が建物を修理、 維持、使用することができる。

第二に、保全地役権を設定した建物に対する増改築や除去、修理、 再建、看板や追加構造物の設置、その他の建物外観に関する変化は、 $\mathrm{CPA}$ による書面での事前承認が必要である。一方、外観の変更を伴 わない通常の定期的な補修管理、修理、清掃、塗装を行うことにつ いては CPAの事前承認を必要としないが、その方法については事前 
承認が必要とされる。従って SACS の場合同様に、ここでも現状変更 に関する情報を事前にCPA が把握できる仕組みとなっている。

第三に、建物の歴史的外観を劣化・減少させる行為をしてはなら ない。改造、除去、物的・構造的変化、修理、清掃、再建、再舗装、 改造、その他建物外観の一切の変化や将来の新規建設は当該建築の 建築的・歴史的特徵と調和し、かつ、オハイオ州シンシナティにお ける $1920 １ 930$ 年代の建築様式に類する建築的特徵を有し、かつ、 市・州・連邦政府の定める修景基準に違反せず調和する建築である ことが求められる。

第四に、自然災害・不慮の事故・等により建物が全壞または半壊 した場合であっても、建物所有者はこれを再建する義務を負わない。 もし再建する場合は、建物所有者が費用を負担し、先に示した調和 や修景基準などの要件を満たす必要がある。

第五に、災害等による建物の全壊・半壊時に備えて、建物所有者 は建物の保険に加入しなければならない。

\section{(3) 保全状態の点検調査}

CPA による点検調查では、建物外観の構成要素をファサード、屋根、 ドレイン、木造部分、空、屝、照明、煙突、付属室等、その他に分類し、 各類型に素材や構成要素などの細目を記入したシートが用いられる。 $\mathrm{CPA}$ スタッフは現地点検時にこのシートを用いて実際の変更点や留 意点を記入する。点検シートには「全体コメント」と問題箇所への 「推奨する対応」を記入する欄が設けられており、建物をよりよい状 態で保全しようとする姿勢が見て取れる。

シートへの実際の記載内容自体は極めて簡単である(表 8)。しかし、 SACS の場合同様にCPA も地権者との契約の中で、建物外観の現状変 更を伴う工事を行う場合は、その計画案は必ず $\mathrm{CPA}$ の事前承認を得 る手続きが契約に定められている。従って CPA は当該年の工事の有 無やその内容に関する情報は持っていることが推察され、現地点検 調查は工事結果を確認する意味合いが強いと言える。

表 8 Cincinnati Bell (1995年) 点検記録概要 (CPA内部資料から筆者作成)

\begin{tabular}{|c|c|}
\hline 点検分類 & 保全地役権の設定対象の状態 \\
\hline 1. ファサード & 良好（Good） \\
\hline 2. 屋根 & 陸屋根のため見えない \\
\hline 3. ドレイン & 良好 \\
\hline 4. 木造部分 & なし $(\mathrm{n} / \mathrm{a})$ \\
\hline 5. 空 & 北面・東面：幾つかの梥で原物の空枠に錆腐食が見られる。 \\
\hline 6. 扉 & 良好 \\
\hline 7. 照明設備 & 良好 \\
\hline 8. 煙突 & なし \\
\hline 9. 付属室等 & 良好 \\
\hline 10. その他雑記 & 彫刻の石灰岩が一部曲がっている（残り9箇所は良好） \\
\hline (○)コメント & ITC（ビル名）としての改修プロジェクトが行われて良好な状態 \\
\hline (○)推奨する対応 & 低層階の腐食した金属空枠の修復、良好な空枠も階別に取り替え検討 \\
\hline
\end{tabular}

\section{4. 歴史保全地役権の慈善寄付に対する減税措置 \\ 4.1 関連税制改正の歴史}

保全地役権の取引に対する最初の優遇税制は 1964 年に連邦歳入庁 が行った自然環境の地役権に対する減税措置である。その後、1976 年税法 (The Tax Treatment Extension Act of 1976) では築 30 年 以上の建物の地役権を保全団体に贈与寸る場合の減税措置が設けら れ、続く 1980 年税法 (The Tax Treatment Extension Act of 1980) において、地役権を民間非営利の保全団体もしくは政府機関等に寄 付する場合は、慈善寄付金 (Charitable contribution) としての所 得控除（項目別控除）と認めるとする減税措置が内国歳入法 170 条
(Internal Revenue Code Section 170 (h) ) において恒久的に定め られた。それまで保全地役権は保全を目的とするトラスト組織等に のみに意義があったものが、これにより土地所有者にとっても保全 地役権を寄付することの金銭的動機が生まれたと言える。

\section{2 減税措置の仕組みと適用条件}

一定の基準を満たす譲渡は「慈善寄付金」と見なされ、寄付者は 調整総所得から項目別控除という形で連邦所得税の減税措置を受け ることができる。慈善寄付金の額は譲渡された保全地役権の価格に 等しく、所得控除額は慈善寄付金の額を上限とする。慈善寄付金とは、 連邦所得税に対寸る項目別控除 ${ }^{14)}$ (実額控除) の一つである。個人 の納税者は、個人所得税の課税所得の計算にあたり、項目別控除ま たは標準控除のどちらか一方（得な方）を選択し、調整総所得から 控除することができる。これが寄付者にとって節税効果を生み出す のである。納税者は原則として各年度の調整総所得の $50 \%$ を限度に 慈善寄付金を控除することができる。控除制限超過額は、翌年以降 5 年間にわたり繰り越すことが可能である。

保全地役権の寄付が慈善寄付金と見なされるには三つの条件を満 たす必要がある。第一に、保全を目的とする永代譲渡 (perpetuity) であること。第二に、寄贈先は州・地方自治体などの政府機関または、 内国歳入法の規定する509 (a) (2) または509 (a) (3)の要件を満たす 501 (c) (3) 認証を受けた慈善団体であること ${ }^{15)}$ ここの第二の条件を 満たす組織は適格組織(Qualified organization) と呼ばれる。第三に、 ナショナルレジスターに登録された物件か、ナショナルレジスター に登録された歴史地区内にある建物・構造物であること。国務長官 (Secretary of the Interior) の定めるナショナルレジスターの基 準を満たしていれば、地方政府の指定する歴史地区であっても同等 と見なされ、地区内の建物はこの第三の条件を満たすことになる。

なお、限られた州ではあるがメリーランド州、バージニア州、コ ロラド州、ノースカロライナ州、ジョージア州等では保全地役権の 寄付に対して州の所得税の税額控除（Tax Credit）を実施している。 税額控除は所得控除と違って算出された税額そのものから減額する ため、寄付者にとっての節税効果は所得控除のそれよりも大きい。

\section{3 保全地役権の鑑定評価}

所得控除額は保全地役権の価格によって決まる。一般的に、歴史 的建造物外観に設定される保全地役権は当該不動産の市場価格の 10 〜 15\%程度 ${ }^{16)}$ と言われており、不動産全体を購入するよりも安価で ある。保全地役権の価格は、保全地役権を設定する前の不動産価格 （A）を、同じ建物状態で保全地役権を設定した後の当該不動産価格 （B）から差し引いた額（B）－（A）として算定する。この算定方法は、 1985 年ニューオーリンズ市フレンチクオーター地区のある歴史的建 造物の保全地役権鑑定評価額を巡って行われた裁判の中で定められ

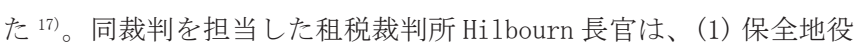
権の価格は保全地役権設定前の建物の最有効使用 (highest \& best use） ${ }^{18)}$ と設定後のそれの差として算定する、（2）既に外観の保全的 規制がかけられているエリアであっても保全地役権の適用によって 建物価值は下がるという見解を示し、以降これが保全地役権の鑑定 評価における大原則となった。なお、各時点での不動産価格は原価 方式・比較方式・収益方式の 3 つの計算方式 ${ }^{19)}$ が一般的に用いられる。 保全地役権の価格は寄付日を基準として算定し、算定図書は 60 日 以内に作成しなければならない。5000 ドル以上の慈善寄付申請を行 
う場合は、認定鑑定士による保全地役権の鑑定評価が必要である。

保全地役権の価格例として、3.3 節Cincinnati Preservation Association が有する保全地役権の一例を表 9 に示す。建物外観と 内観に保全地役権が設定されているWaldo Building の場合、外観改 修を行った状態で保全地役権設定前の価格が 195 万ドル、同じく設 定後の価格は 181 万ドル、従って保全地役権の価格は 14 万ドルと算 定される。この場合、個人連邦所得税率は課税収入に応じて 15.0 39. 6\%（1988 年時点）の幅で定められていることから、仮に評価額 14 万ドルの保全地役権を慈善寄付金として処理すれば、概算で 2 万 1000 ドル〜 5 万 5440 ドル相当の減税効果が生まれることになる。

表 9 保全地役権の価格例（参考文献 27,28, 29 を元に筆者作成）

\begin{tabular}{|c|c|c|}
\hline 建物 & 価格 & 特徵 \\
\hline $\begin{array}{ll}400 & \text { Reading } \\
\text { Road } & \text { Building } \\
\text { (図 } 4 \text { 左) }\end{array}$ & $\$ 138,000^{-}$ & \multirow{2}{*}{ 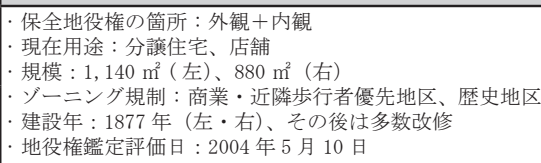 } \\
\hline $\begin{array}{|ll|}404 & \text { Reading } \\
\text { Road } & \text { Building } \\
\text { (図 4 右) } \\
\end{array}$ & $\$ 139,000-$ & \\
\hline $\begin{array}{l}\text { Waldo Building } \\
\text { (図 5) }\end{array}$ & $\$ 140,000^{-}$ & 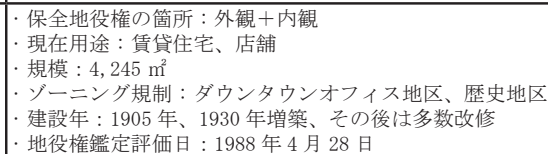 \\
\hline
\end{tabular}

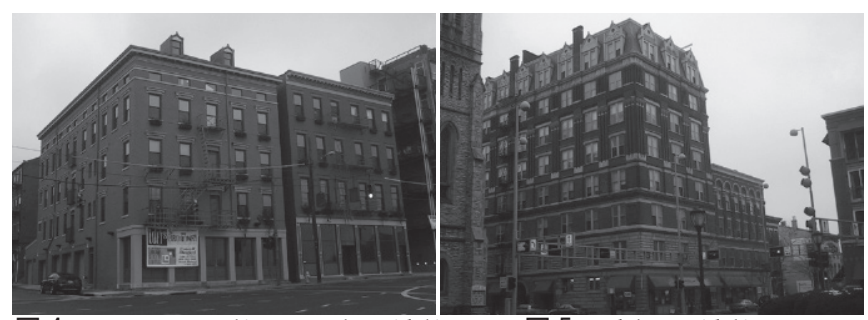

図 4 400-404 Reading Road Building 図 5 Waldo Building

\section{4 所得控除を活用した資金調達}

所得控除による減税措置は、仮に額が大きくてもそれに見合った 所得がなければ、例え 5 力年の繰り越し措置があっても使い切れな いという弱点がある。この点について例えばオ八イオ州のクリーブ ランド市では、所得控除を受けることのできる主体（ここでは A と する）が地域の金融機関と債権引受組合（Syndication）を組むこ とによって克服している ${ }^{20)}$ 。この場合、金融機関が A の所得控除額 と同額を出資することによって債権引受組合を設立する。A はこの 出資金から金融機関側の手数料等を差し引いた額の現金を受け取る ことで、所得控除を現金に置き換えることができる。受け取った現 金は自身の建物の改修のために使用される。一方で、金融機関にと っては債権引受組合設立のための出資が税額控除（investment tax credit）として認められるため、出資金が税額控除によって相殺され ることになる。例えば、1890 年に建設された The Arcade を2001 年 にホテル等に改修転用した事例（図 6、図 7）では、地権者が地元の 街づくり組織 Historic Gateway Neighborhood Corporation(HGNC) に保全地役権を寄贈することで 600 万ドルの所得控除を得た。さら に地権者は建物改修資金を得るために、地元オ八イオ州の金融機関 と債権引受組合を設立し、地役権設定により得られた所得控除を用 いて約 550 万ドルの資金を調達した。HGNC は同手法を地域内で展開 して他に 11 件の歴史的建造物の改修に貢献した実績がある ${ }^{211}$ 。

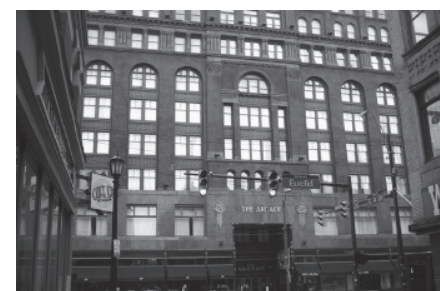

图 6 The Arcade 外観

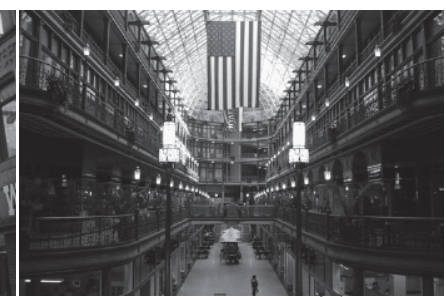

図 7 The Arcade 内観

\section{5. 考察}

歴史保全手法として HCEP には 5 つの利点があると考えられる。 第一に保全地役権という概念がもたらす利点について。保全地役 権は土地所有権の中から保全目的に反した活動を行う権利だけを法 的に制限したものである。従って、地役権を設定する外観等の変更 等を行わないなど保全目的に反しない限り、建物所有者は従前の建 物利用をそのまま継続できる。保全行為が日常の生活や業務等に実 質的影響を及ぼさないため柔軟性の高い保全手法と言える。

第二に保全地役権を設定することがもたらす利点について。まず、 HCEP は TDR のように潜在的な開発可能性を別の土地一移動させるの ではなく、潜在的な開発可能性を直接的に減ずることによって歴史 的建物を保護している。従って、周辺に大規模開発を生み出さない ため、建物単体に留まらず歴史的環境の面的な保護が実現できる。 また、開発可能性を直接的に減ずるということは、大規模開発圧力 が低いエリアでも活用可能なことを意味する。従って、衰退空洞化 している地方都市中心市街地や郊外低層戸建て住宅街等の多様なエ リアで活用できる汎用性を有していると言える。

第三に HCEP の手続きがもたらす利点について。保全地役権の設定 には行政手続きが不要であり、土地所有者と保全団体の二者のみの 合意があれば任意の箇所に設定できるという手軽さがある。また、 保全地役権の維持管理には定期的な建物点検調查が必要とされる。 この際に、建物の現状変更には地役権保有組織の承認が必要になる ため、現状変更の動向と変更内容は同組織が必ず把握できる。なお かつ、現状変更工事の結果確認、良好な保全状態維持に必要な追加 修繽箇所の指摘、近い将来の現状変更可能性の把握が行えるため、 建物の保全状態の維持と向上を同組織は働きかけることができる。 つまり、同組織の運用次第では単なる機械的検查を越えた能動的な 保全活動としての検查が行える。

第四に保全地役権の設定がもたらす金銭的メリットについて。一 般に歴史的建造物の外観に設定される保全地役権の価格は当該不動 産の市場価格の $10 \sim 15 \%$ 程度といわれている。もし、歴史的建造 物を保全するために土地を含めた所有権全体を買い取とるならば、 保全目的に反しない活動を行う権利まで買い取ることになり、歴史 的環境保全という目的に対して割高のコストを支払うことになる。 その点 HCEP はより少ないコストで法的強制力を持った歴史的環境の 保全を行う可能性を切り開いていると考えられる。

第五に慈善寄付に対する所得控除という仕組みのメリットについ て。この仕組みは、修復事業を行わなくても税制優遇の適用を受け られることを意味している。そのため、差し当たって修復のための 財源が確保できていないが建物保護の措置が必要なケースにも適用 できるなど汎用性が高い仕組みと考えられる。また、一般に建物の 修復事業を行うと当該建物の資産価值が増大寸ることから建物にか 
かる財産税は上昇してしまうが、HCEP を用いる場合はそのような税 負担増も回避することができると言える。

以上を踏まえ、歴史的環境保全手法としての日本一の導入課題と して 3 点を指摘したい。第一に長期的には米国同様の保全地役権概 念の確立が望まれるが、先ずは「ある土地・建物の保全目的に反す る活動を行う権利」の明確な概念化である。土地に関する権利とし て確立すれば都市計画制度としての適用可能性も広がる。第二に土 地・建物の保全目的に反する活動を行う権利を制限することに対し て税制優遇等のインセンティブ制度づくりである。建物を壊すより も改修して残すほうが金銭的メリットが大きいと個々の地権者が判 断できるような多数の制度的選択肢が求められる。第三に地元組織 が柔軟にオーダーメード可能な手法としての制度設計である。米国 の HCEP を運用する組織は地元密着型というより、保全目的で広範囲 に活動する組織が多い。しかしながら我が国の歴史的環境保全の取 り組みは全国組織による制度的支援よりも、地域の信頼を得た地元 組織による草の根的サポートによる貢献が大きいと思われる。こう した条件下でも利用しやすい制度としての構築が課題と言えよう。

\section{参考文献}

1）西村幸夫 : 都市保全計画, 東京大学出版会, 2004

2) 西村幸夫 : 環境保全と景観創造, 鹿島出版会, 1997

3) 矢作弘：町並夕保存運動 in USA, 学芸出版社, 1989

4) 西浦定継, 平修久 : 米国メリーランド州の農地等保全政策の発展と問題点 について, 都市計画論文集, No.43-3, pp.361-366, 2008

5) 田口太郎, 後藤春彦, 佐藤宏亮 : ニューヨーク州 Westchester Land Trust による環境管理手法に関する研究, 日本建築学会大会学術講演梗概集, F-1 分冊, pp.1163-1164, 2007

6) 新澤秀則 : 保全地役権について, 神戸商科大学研究年報, No. 32, pp.25-34, 2002.4

7）坂井千之：英米法における地役権 Easementsについて（1），札幌国際大 学紀要, 第 31 号, pp.87-93, 2000

8）小澤英明：景観地役権，判例タイムズ No.1011, 50[26], pp.28-34, 1999.12

9）日端康雄編著・容積率研究会著：都市再生を目指して〜建築空間の容積移 転とその活用，清文社， 2002

10) Stephen L. Kass, Judith LaBelle, David Hansell: "Rehabilitating Older and Historic Buildings: Law Taxation Strategies", John Wiley \& Sons, Inc., 1993

11) John B. Wright: "Designing and Applying Conservation Easements", Journal of American Planning Association, 60[3]: 380-388,1994

12) Brian W. Ohm: "The Purchase of Scenic Easements and Wisconsin's Great River Road: A Progress Report on Perpetuity”, Journal of American Planning Association, 66[2]: 177-188, 2000

13) Diehl, J. and T. S. Barrett: "The Conservation Easement Handbook, Managing Land Conservation and Historic Preservation Easement Programs", Land Trust Alliance., 1988

14) Watson, A. Elizabeth: "Establishing an Easement Program to Protect Historic, Scenic, and Natural Resources", National Trust for Historic Preservation, Washington, D.C., 1982

15) National Park Service; U.S. Dept. of the Interior; National Center for Cultural Resources Heritage Preservation Services Division, Technical Preservation Service: "Historic Preservation Easements: A Directory of Historic Preservation Easement Holding Organizations“, 2003

16) Jefferson \& Lee Appraisals, Inc.: "Appraisal Report: Loss in Value Due to a Conservation Easement To Be Donated on The Rawson Building 321325 South Main Street, Findlay, Ohio 45840”, as of Nov.18, 2004

17) National Conference of Commissioners on Uniform State Laws: "Uniform Conservation Easement Act”, 1981

18)Plotka, Robert: "Conservation easement made easy, with five steps",
Real Estate Weekly, Dec. 1, 2004

19) Public Law 26 U.S.C. 170(h); Qualified Conservation COntributions 20) Public Law 26 U.S.C. 47; Rehabilitation credit

21) Hilborn v. Commissioner, 85 T.C. 677 (U.S. Tax Ct. 1985)

22) Cincinnati Preservation Association: "Cincinnati Preservation Association, List of Easement Properties", as of 1/10/2005

23) "Grant of Easement, Covenants and Restrictions", granted on 1/31/1996, by and between Cincinnati Bell Telephone Company and Cincinnati Preservation Association

24) "Grant of Easement, Covenants and Restrictions for Preservation of Architectural and Historic Features of the Waldo Building”, granted on 12/30/1988, by and between Greater Cincinnati Historical Properties Ltd., and Miami Purchase Association for Historic Preservation

25) Chapman \& Co.: "Waldo Building 204 West Eight Street, Cincinnati, Ohio”, prepared for M. Jay Andress 3906 Oak St. Cincinnati, Ohio, 1988

26) Cincinnati Preservation Association: "Easement monitoring documents: Cincinnati Bell", as of 4/15/2004

27) Cincinnati Preservation Association: "Easement monitoring documents: Waldo Apartment", as of 4/15/2004

28) Lionel Socol Certified General Appraiser: "Appraisal of Real Property, Located at 400 Reading Road, Cincinnati, Ohio", as of May 10, 2004 29) Lionel Socol Certified General Appraiser: "Appraisal of Real Property, Located at 404 Reading Road, Cincinnati, Ohio ”, as of May 10, 2004 30) Land Trust Alliance: "Appraising Easements, Guidelines for Valuation of Land Conservation and Historic Preservation Easements", 3rd Ed., 1999

31) The Historic Warehouse District Development Corporation: "An Easement Program for the Historic Warehouse District Development Corporation”, Prepared by Clarion Associates, Inc.; Chicago, IL, 1997

注

注 1)Historic Preservation Easement Program と呼ばれることもある。

注 2）西浦・平（2008） は米国メリーランド州で行われている農地の保全地役 権の買い取り制度について実態を調査分析し、農地保全施策としての課題 等を考察している。田口・後藤・佐藤（2007）は地域環境管理手法として 空地の保全地役権の寄付プログラムに着目し、ニューヨーク州 Westchester Land Trust 社を介した土地保全の仕組みの分析を行い、我が国における応 用可能性について考察している。アメリカでは、Brian W. Ohm (2000) がウ ィスコンシン州ミシシッピー川沿いグレート・リバー・ロード周辺の風景保 全を目的とする保全地役権の買い取り事例について分析し、制度運用にかか る課題を考察している。また、John B. Wright (1994) がランド・トラスト 社のプログラム利用動向を分析し、自然環境の保全手法として評価している。 注 3) 参考文献 15

注 4) 分析対象とする 2 組織以外に現地調查を行った組織は、Maryland Historical Trust, Historic Landmarks Foundation of Indiana, Rhode Island Historical Preservation \& Heritage Commission の 3 組織。

注 5) 米国には習慣法（common law）と衡平法（equity）という二つの法体系 が存在する。いずれの法体系においても元来は付随性を要求する概念として 扱われていたが、付随地役権だけでは環境保全の要請に十分に応えることが できないため、習慣法の中に新しく保全地役権が制定された。

注 6) 要役地とは、地役権が設定されたとき、承役地から便益を受ける土地で ある。一方の承役地とは、要役地のために便益を供する土地を指す。例えば、 要役地の利用のために通路となる土地等は承役地である。

注 7) 通行地役権、流水・用水地役権、採光地役権、通風地役権、等が該当寸る。 注 8）日本の地役権は民法第 $280 \sim 294$ 条に規定される。米国の付随地役権と 同様に、他人の土地（要役地）を自分の土地（承役地）の便益のために利用 する権利であり、二つの土地の所有者間で契約により発生する権利である。 注 9) 統一地役権法における保全地役権の定義は次の通り。“Conservation easement" means a non-possessory interest of a holder in real property imposing limitations or affirmative obligations the purposes of which include retaining or protecting natural, scenic, or open-space values of real property, assuring its availability for agricultural, forest, 
recreational, or open-space use, protecting natural resources, maintaining or enhancing air or water quality, or preserving the historical, architectural, archaeological, or cultural aspects of real property.

注 10) 正式名称は The National Conference of Commissioners of Uniform State Laws である。州法の統一性を促進するために 1892 年に組織された。 各州とワシントン特別区、プエルトリコの代表者で構成されている。

注 11) TDR はある土地の開発権の一部を他の土地へ移転することを認める制度。 注 12) 参考文献 11

注 13)CPA は保全地役権設定の申請時に契約書の雛形を申請者に提示し、これ に基づいて契約を進める。Cincinnati Bell の契約書もこの雛形と同じ契約 条項によることから、分析対象としての代表性を備えていると言える。

注 14）項目別控除を構成するのは、医療費控除、諸税控除、支払利息控除、慈 善金寄付控除、災害および盗難損失控除、杂隹控除である。

注 15) 501(c)(3) 認証組織とは、宗教、教育、慈善、科学、芸術、公共の安 全、アマスポーツ育成、子供や動物の虐待防止等を目的とする組織である。 509(a)(2) 要件とは活動財源の実質的な部分を政府機関からの免除対象収入・ 補助金・助成金もしくは公共的な慈善寄付から得ている組織であること。 509(a)(3) 要件とは他の慈善組織や連邦税の免除組織を支援寸るための組織
であること。

注 16) 参考文献 18

注 17) 参考文献 21

注 18）最有効使用とは不動産の最も高い価值を生み出す合理的かつ実際に可能 な用途のこと。法的可能性、物的可能性、資金的実現可能性、最大生産性と いう4つの観点から各価格を算出し最も高い価格を生み出す用途である。

注 19) こ原価方式とは不動産の再調達原価に着目した価格算定法である。比較 方式とは取引事例や賃貸事例に着目した比較による算定法である。収益方式 とは不動産から生ずる収益に着目する算定法である。

注 20）筆者が米国内の北東部・中西部・南部の 21 都市で行った聞き取りプ レ調査によると、ここに紹介する手法はクリーブランド市で活動する街づ くり組織 (Historic Warehouse District Development Corporation および Historic Gateway Neighborhood Corporation）が HCEP 運用に関与した建 物だけに確認された独自性の強い手法であった。

注 21） 2003 年 9 月 9 日 HGNC 社長 Tom Yablonsky 氏インタビュー調査による。 